\title{
The Evaluation of Indoor Microbial Air Quality in Two New Commissioning Higher Educational Buildings in Johor, Malaysia
}

\author{
Chin Ming $\mathrm{Er}^{1, \mathrm{a} \star}$, N. M. Sunar ${ }^{2, \mathrm{~b}}$, A. M. Leman ${ }^{2 . \mathrm{c}}, \mathrm{N}^{1}$ Othman $^{1, \mathrm{~d}}$, Q. Emparan ${ }^{1, \mathrm{e}}$, \\ U. K. Parjo ${ }^{1, f}$, P. Gani ${ }^{1, g}$, N. A. Jamal ${ }^{1, h}$, N. A. Ideris ${ }^{1, i}$
}

${ }^{1}$ Department of Water and Environmental Engineering, Faculty of Civil and Environmental Engineering, University Tun Hussein Onn Malaysia, 86400 Parit Raja, Batu Pahat, Johor, Malaysia

${ }^{2}$ Department of Chemical Engineering Technology, Faculty of Engineering Technology (FTK), Universiti Tun Hussein Onn Malaysia, 86400, Parit Raja, Batu Pahat, Johor, Malaysia

aerchinming@hotmail.com, bshuhaila@uthm.edu.my, ${ }^{\mathrm{c}}$ mutalib@uthm.edu.my,

dnorzila@uthm.edu.my, ${ }^{\mathrm{e}}$ quinston89@gmail.com, ${ }^{\mathrm{f}}$ umi5506@yahoo.com, gparancgat@yahoo.com, hdf090252@siswa.uthm.edu.my, 'atiyalurve89@gmail.com

Keywords: indoor microbial contamination, bioaerosols, air sampling

\begin{abstract}
The proliferation of indoor airborne microorganism in public institutional buildings such as schools and universities is often regarded as a potential health hazards to the buildings' users. This issue is not new in Malaysia, a country with humid climate which favours the growth of microorganism. However, there is lack of research's data, especially in higher institutional buildings in this country. The assessment of the indoor air quality is conducted in a university's two new commissioning buildings located at Southern Peninsular of Malaysia. Both buildings utilized centralized air conditioning system. Concentrations of airborne microorganism were determined using a single-stage impactor (biosampler) as per requirement of National Institute of Occupational Safety and Health (NIOSH) Manual Analytical Method 0800. The acquired readings were compared to the standard level determined in Industry Code of Practice on Indoor Air Quality (ICOP IAQ) 2010. Other parameters such as relative humidity, temperature, and air velocity were recorded along the assessment. The mean concentrations of the total bacteria at the affected area of the two buildings are $1102.5 \mathrm{CFU} / \mathrm{m}^{3}$ and $813 \mathrm{CFU} / \mathrm{m}^{3}$ respectively and it is significantly higher compared to the maximum exposure limit of $500 \mathrm{CFU} / \mathrm{m}^{3}$. While, the mean concentration of total fungi at the affected area for two buildings are $805.7 \mathrm{CFU} / \mathrm{m}^{3}$ and $509 \mathrm{CFU} / \mathrm{m}^{3}$ respectively which are both higher than the reading of outdoors and unaffected indoor area although slightly lower than the maximum exposure limit of $1000 \mathrm{CFU} / \mathrm{m}^{3}$. This study provides a glance of the poor indoor microbiological air quality in new higher institutional buildings in this humid region.
\end{abstract}

\section{Introduction}

Indoor air quality (IAQ) is gaining attention as a major concern to building managers, tenants and workers as most people spend most of their lifetime in confined spaces such as public places and offices. IAQ is the air quality inside a building that leads to the comfort and healthy of the occupants [1]. It can be affected by gases, particulates, microbial contaminants or any mass or energy stressor that can induce adverse health conditions. Bad IAQ can lead to sick building syndrome (SBS), a condition which people feel uneasy such as headache, sleepiness or inability to concentrate by spending time in certain buildings. SBS is caused by the presence of high concentrations of indoor air pollutants, especially those biological agents [2]. The indoor microbial pollutants include fungal and bacterial contaminants and their derivatives, viruses and pollens. These bioaerosols can be pathogenic or cause adverse health effects such as allergic reaction following inhalation, especially in people with asthma. They are originated from outdoor air, handling of organic materials and other human activities such as walking, talking, sneezing and toilet flushing [3]. Besides, the building materials and ventilation system can be the sources of indoor airborne microbes [4]. Thermal comfort is an important physical component of IAQ as factors like relative humidity and temperature affects indoor airborne microbial growth [5]. 
Previous researches have shown that there were significant amounts of airborne microorganisms present in a clean room [6]. Therefore, it is reasonable for the existence of airborne microorganism in new commissioning buildings. There are also evidences from studies indicating that a significant background level of airborne microbe exist in a new constructed office building [7]. These bioaerosol should be controlled within a safety level. Hence, there is a need to assess the IAQ of buildings periodically even in new buildings to ensure their IAQ are always within the allowable limit set by local or international authorities. In Malaysia, Industry Code of Practice for Indoor Air Quality (ICOP-IAQ) 2010 of the Department of Occupational Safety and Health (DOSH) addresses the recommendation on the allowable limit for the concentration of these indoor bioaerosols [8].

Many studies regarding to indoor microbiological air quality have been conducted [9-13]. However, the data of the assessment of indoor microbial contamination in Malaysia or other Southeast Asian countries which share common hot and humid climate was very limited [14-19]. There was only a study on mold growth in a university's clinic in Malaysia [16] but not in its educational buildings. From the educational point of view, the IAQ in educational buildings may affect educators' and students' well-being and their teaching and learning performances [20]. Hence, it is essential to evaluate the air quality in university's buildings in order to reveal its situation of accumulation and diffusion of bioaerosol contamination. Thus, this research aimed to evaluate the microbiological air quality in two new commissioning higher educational buildings of a university in Johor, Malaysia and to compare the measured concentrations with established standards.

Johor is the southernmost region of Peninsular Malaysia. This region is characterized with high air temperature, high relative humidity and seasonal pattern of wind and rainfall [21]. These climatic characteristic are favourable for microorganism growth and affect IAQ. The limited IAQ studies done in this region mainly cover the physical parameters of IAQ such as temperature, relative humidity, air movement, and $\mathrm{CO}_{2}$ but microbiological data is very limited [21-22]. Moreover, these previous studies were neither conducted in new commissioning building nor higher educational buildings. Thus, this study is able to provide missing information about indoor air healthiness of new commissioning higher educational buildings in Johor, Malaysia from a viewpoint of microbiological and thermal comfort.

\section{Materials and Methods}

The two new higher educational buildings (refer as B1 and B2) with water-damaged characteristic were recruited. Complaints were logged for indoor presence of visible microbial stains and odour. Specific sampling sites were identified by walk through inspection. The selected area was taken at one each to represent a complained area, a non-complained area and outdoors.

Concentrations of total airborne microbes were determined using a BioStage single-stage impactor (SKC, USA). It was operated at a flow rate of $28.3 \mathrm{~L} / \mathrm{min}$ as per requirement of National Institute of Occupational Safety and Health (NIOSH) stated in method NIOSH Manual Analytical Method (NMAM 0800). The impactor was mounted at the centre of the sampling sites at a height of 1.0 to 1.5 meter above the floor. Every sample was obtained over 5 minute periods. The Trypcase Soy Agar (TSA) was used to sample total airborne bacteria while the Malt Extract Agar (MEA) for total airborne fungi. Each sample was plated in triplicate. The sampling at different sites was performed on different day for a total of 42 days; during office hours and in the presence of lecturers and students. After the impaction, the petri dishes were sealed, placed into a disinfected cool box to inhibit microbe growth and brought into the laboratory. The total airborne bacteria samples were incubated at $37^{\circ} \mathrm{C}$ for 2 days and counting of colonies formed was done thereafter. While, the total fungi sample was analyzed by incubating them at $37^{\circ} \mathrm{C}$ for 5 days. The enumeration of the sample is represented by colony forming unit (CFU) analysis as the calculation below:

$$
\mathrm{CFU} / \mathrm{m}^{3}=[\text { Number of colonies } \times 1000] \div[\text { Sampling time }(\mathrm{min}) \times \text { Flow rate }(\mathrm{L} / \mathrm{min})] \text {. }
$$


The data of air temperature, relative humidity and air velocity is recorded with Lutron LM-8000 (Lutron, Taiwan) in accordance to each collection of subject samples. All the data is collected by operating the instrument at the shoulder level of seated person according to ICOP-IAQ 2010 [8].

\section{Results and Discussion}

The experiments were an investigation into numbers of total fungi and total bacteria present in the air. Through preliminary walk through investigation to these buildings, surface stains and visible microbial growth were observed on the painted brick wall surface, ceiling boards and some furniture. Researches stated that presence of mouldy partition or decomposed wall always becomes the first choice indicator of indoor bioaerosol exposure [23]. B1 is for higher education of computer studies while B2 is for civil engineering studies. Three sampling sites were selected at each building. For B1, they were the complained prayer room (C1), non-complained Lecturer Rooms' Lobby (NC1) and outdoors (O1). Meanwhile, for B2, the sampling sites are complained Lecturer Room 146 (C2), non-complained Chemical Engineering laboratory (NC2) and outdoors (O2).

Table 1 shows the result of physical IAQ assessment at B1 and B2. There was zero air velocity observed in both buildings but some air movement was observed at outdoors. The relative humidity and air velocity of the affected $\mathrm{C} 1$ and $\mathrm{C} 2$ fell out of the recommended guidelines suggested by ICOP-IAQ 2010. This is dangerous and may bring unintended contaminations that will cause bad air quality in the buildings as the excess water is known to be the most significant individual factor associated with the elevated viable fungal counts indoor [24].

Table 1: Results of IAQ physical parameters compared to ICOP-IAQ 2010 standard guideline.

\begin{tabular}{|c|c|c|c|c|c|c|c|}
\hline \multirow[t]{2}{*}{ Parameters } & \multicolumn{3}{|c|}{ B1 } & \multicolumn{3}{|c|}{ B2 } & \multirow{2}{*}{$\begin{array}{c}\text { ICOP-IAQ } \\
(\mathbf{2 0 1 0 )} \\
\text { Acceptable Limit }\end{array}$} \\
\hline & $\begin{array}{c}\mathrm{C} 1 \\
{[\mathrm{n}=3]}\end{array}$ & $\begin{array}{c}\mathrm{NC1} \\
{[\mathrm{n}=3]}\end{array}$ & $\begin{array}{c}\mathrm{O} 1 \\
{[\mathrm{n}=3]}\end{array}$ & $\begin{array}{c}\mathrm{C} 2 \\
{[\mathrm{n}=3]}\end{array}$ & $\begin{array}{c}\mathrm{NC} 2 \\
{[\mathrm{n}=3]}\end{array}$ & $\begin{array}{c}\mathrm{O} 2 \\
{[\mathrm{n}=3]}\end{array}$ & \\
\hline Relative humidity [\%] & 87 & 67.8 & 69 & 90 & 74 & 78.2 & $40-70$ \\
\hline Temperature $\left[{ }^{\circ} \mathrm{C}\right]$ & 25.3 & 27.7 & 31.5 & 25 & 24.4 & 28.9 & $23-26$ \\
\hline Air velocity $[\mathrm{m} / \mathrm{s}]$ & 0 & 0 & 0.7 & 0 & 0 & 0.1 & $0.15-0.5$ \\
\hline
\end{tabular}
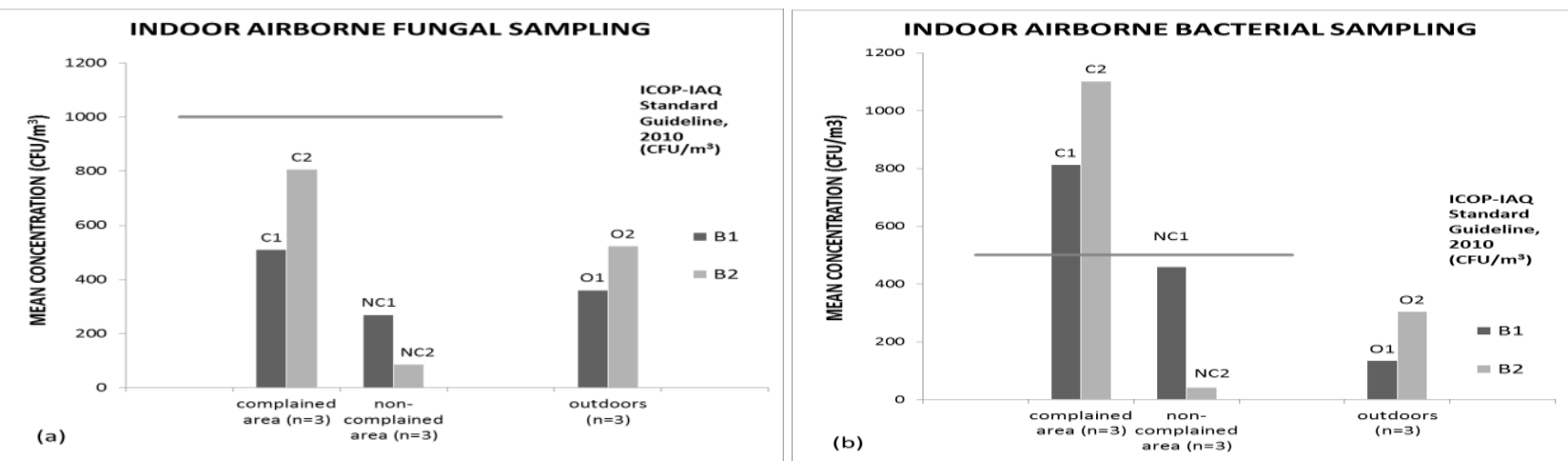

Figure 1: Indoor and outdoor air samplings for (a) fungus and (b) bacteria.

In $\mathrm{B} 1$, the mean concentration of the total airborne bacteria in the complained $\mathrm{C} 1$ is $813 \mathrm{CFU} / \mathrm{m}^{3}$ (Figure 1). This is far higher than that of the allowable limit stated in ICOP-IAQ $2010\left(500 \mathrm{CFU} / \mathrm{m}^{3}\right)$ and that of the building's outdoor environment $\left(134 \mathrm{CFU} / \mathrm{m}^{3}\right)$. The mean concentration of the total bacteria at the non-complained area, $\mathrm{NC1}$ is also approaching the limit. Meanwhile, the mean concentration of the total airborne fungi in the affected $\mathrm{C} 1$ is $509 \mathrm{CFU} / \mathrm{m}^{3}$. Although it is within the allowable limit $\left(1000 \mathrm{CFU} / \mathrm{m}^{3}\right)$, it is still higher than that of outdoor environment of the building $\left(360 \mathrm{CFU} / \mathrm{m}^{3}\right)$. Besides, the samples were taken after some physical mold remediation of the affected room including changing of the ceiling board and cleaning of the wall using detergent. However, $509 \mathrm{CFU} / \mathrm{m}^{3}$ is actually not a low count after such remediation. High relative humidity in $\mathrm{C} 1(87 \%)$, which violates the limit of ICOP-IAQ justifies high reading of colony forming units of both total airborne bacterial and total airborne fungal counts obtained in that room. 
For $\mathrm{B} 2$, the relative humidity of the affected $\mathrm{C} 2$ recorded a high reading of $90 \%$ as compared to $74 \%$ in the unaffected NC2. This can explain the mold devastation in the affected room as fungal growth requires high moisture contents. This is consistent with our results as the total airborne fungal count in the affected $\mathrm{C} 2$ is $805.7 \mathrm{CFU} / \mathrm{m}^{3}$. This is approaching the acceptable limit of 1000 $\mathrm{CFU} / \mathrm{m}^{3}$ set by ICOP-IAQ 2010. Nevertheless, the reading is still higher than that of outdoors, which is $523 \mathrm{CFU} / \mathrm{m}^{3}$. The mold infestation on the wall and furnishing in this room is easily seen through visual inspection. Meanwhile, the total airborne bacterial count in $\mathrm{C} 2$ is $1102.5 \mathrm{CFU} / \mathrm{m}^{3}$. This has far exceeded the limit set by ICOP-IAQ 2010, which is $500 \mathrm{CFU} / \mathrm{m}^{3}$ only.

The mean concentrations of indoor microbes at all complained sites are higher than that of their respective building's outdoors. It is suggested that the microorganism was brought from outdoors and contained indoors due to zero air movement observed in those complained areas. In addition, the systems of air-conditioning in both buildings are centralized, thus it is assumed that the airborne spores will be spread and may cause microbial contamination at other sites. This can explain the high concentrations of total bacteria in the air of non-complained area of B1. Both buildings were equipped with all types of facilities to ease students' studies. There are high access of students, lecturers and visitors to these buildings and sampling sites. Thus, it can be assumed that all types of human activities happened here had contributed to the poor IAQ. For example, the complained C1 is a room for prayer purposes and is equipped with washing taps. The washing activity in the room might be the main reason of high moisture content. Undeniably, Malaysia's hot and humid climate also contributes to high relative humidity in these buildings.

\section{Conclusion}

This study shows that some parts of the two new commissioning higher educational buildings in Johor, Malaysia have been contaminated by indoor airborne microbes. The thermal comfort parameters measured in these buildings did not comply with the recommended values. Although the higher educational buildings in this region is newly commissioning, poor indoor microbial air quality and thermal comfort were observed. This study provides insight that new higher educational buildings in this region should be assessed and maintained for the best comfort of the indoor occupants. It is recommended that the remediation steps with low cost, eco-friendly and sustainable solution should be taken as the yearlong humid climate in this region will make the normal cleaning procedure ineffective and costly.

\section{Acknowledgement}

The authors greatly appreciate Universiti Tun Hussein Onn Malaysia (UTHM) and National Institute of Occupational Safety and Health Malaysia (NIOSH) for facilitating the works.

\section{References}

[1] Yau, Y. H., Chew, B. T., \& Saifullah, A. Z. A. (2012). Studies on the indoor air quality of Pharmaceutical Laboratories in Malaysia. International Journal of Sustainable Built Environment, 1(1), 110-124.

[2] Takigawa, T., Wang, B. L., Sakano, N., Wang, D. H., Ogino, K., \& Kishi, R. (2009). A longitudinal study of environmental risk factors for subjective symptoms associated with sick building syndrome in new dwellings. Science of The Total Environment, 407(19), 5223-5228.

[3] Gots, R. E., Layton, N. J., \& Pirages, S. W. (2003). Indoor health: background levels of fungi. AIHA journal, 64(4), 427-438.

[4] Pastuszka, J. S., Kyaw Tha Paw, U., Lis, D. O., Wlazło, A., \& Ulfig, K. (2000). Bacterial and fungal aerosol in indoor environment in Upper Silesia, Poland. Atmospheric Environment, 34(22), 3833-3842. 
[5] Dangman, K. H., Schenck, P., DeBernardo, R. L., Yang, C. S., Bracker, A., \& Hodgson, M. J. (2004). Guidance for clinicians on the recognition and management of health effects related to mold exposure and moisture indoors. Farmington, CT: University of Connecticut Health Center, Division of Occupational and Environmental Medicine, Center for Indoor Environments and Health.

[6] Favero, M. S., Puleo, J. R., Marshall, J. H., \& Oxborrow, G. S. (1966). Comparative levels and types of microbial contamination detected in industrial clean rooms. Applied microbiology, 14(4), 539-551.

[7] Abidin, A. S. Z., Leman, A. M. \& Noraini, N. M. R. (2011). Background Level of Microbe in New Office Building. Journal of OCCUPATIONAL, 25.

[8] Department of Occupational Safety and Health. Ministry of Human Resources. Industry code of practice on indoor air quality. 2010. JKKP DP (S) 127/379/4-39.

[9] Krause, M., Geer, W., Swenson, L., Fallah, P., \& Robbins, C. (2006). Controlled study of mold growth and cleaning procedure on treated and untreated wet gypsum wallboard in an indoor environment. Journal of occupational and environmental hygiene, 3(8), 435-441.

[10] Maclntosh, D. L., Brightman, H. S., Baker, B. J., Myatt, T. A., Stewart, J. H., \& McCarthy, J. F. (2006). Airborne fungal spores in a cross-sectional study of office buildings. Journal of occupational and environmental hygiene, 3(7), 379-389.

[11] Lee, J. A., Johnson, J. C., Reynolds, S. J., Thorne, P. S., \& O'shaughnessy, P. T. (2006). Indoor and outdoor air quality assessment of four wastewater treatment plants. Journal of occupational and environmental hygiene, 3(1), 36-43.

[12] Ramachandran, G., Adgate, J. L., Banerjee, S. et al. (2005). Indoor air quality in two urban elementary schools-Measurements of airborne fungi, carpet allergens, $\mathrm{CO} 2$, temperature, and relative humidity. Journal of occupational and environmental hygiene, 2(11), 553-566.

[13] Tranter, D. C., Wobbema, A. T., Norlien, K., \& Dorschner, D. F. (2009). Indoor allergens in Minnesota schools and child care centers. Journal of occupational and environmental hygiene, 6(9), 582-591.

[14] Lian, K. S., Nila, I., and Ahmad, R. (2007). "Sources of Indoor Air Quality Problem in a New Hospital in Malaysia." The 6th International Conference on Indoor Air Quality, Ventilation \& Energy Conservation in Buildings, Sendai, Japan.

[15] Ismail, S.H., Deros, B.M. and Leman, A.M. (2010). Indoor Air Quality Issues for NonIndustrial Workplace. IJRRAS 5 (3).

[16] Wardah, A.R., Hafizi, R., Siti Nurdijati, B. and Salleh, B. (2011). Incidence and remediation of fungi in sick building in Malaysia- A case study. Aerobiologia, 28(2), 275-283.

[17] Hussin, N.H.M., Sann, L.M., Shamsudin, M.N., and Hashim, Z. (2011). Characterization of Bacteria and Fungi Bioaerosol in the Indoor Air of selected Primary Schools in Malaysia. Indoor and Built Environment, 20(6), 607-617.

[18] Sekhar, S. C., Tham, K. W., and Cheong, K. W. (2003). Indoor air quality and energy performance of air-conditioned office buildings in Singapore. Indoor air, 13(4), 315-331.

[19] Luksamijarulkul, P., Panya, N., Sujirarat, D., and Thaweboon, S. (2009). Microbial air quality and standard precaution practice in a hospital dental clinic. Journal of the Medical Association of Thailand $=$ Chotmaihet thangphaet, 92, S148.

[20] Daisey, J. M., Angell, W. J., \& Apte, M. G. (2003). Indoor air quality ventilation and health symptoms in schools: an analysis of existing information. Indoor Air, 13, 53-64.

[21] Nugroho, A. M., Ahmad, M. H., \& Ossen, D. R. (2007). A preliminary study of thermal comfort in Malaysia's single storey terraced houses. Journal of Asian Architecture and Building Engineering, 6(1), 175-182.

[22] Sulaiman, Z., \& Mohamed, M. (2011). Indoor air quality and sick building syndrome study at two selected libraries in Johor Bahru, Malaysia. Environment Asia, 4(1), 67-74.

[23] Wong, L. T., Mui, K. W., Hui, P. S., Chan, W. Y., \& Law, A. K. Y. (2008). Thermal Environmental Interference with Airborne bacteria and Fungi Level in Air-Conditioning Offices. Indoor and Built Environment, 17(2), 2.

[24] Green, C.F.; Scarpino, P.V.; Gibbs, S.G. (2003) Assessment and modeling of indoor fungal and bacterial concentrations. Aerobiologia, 19:159-169. 